\title{
Emerging Viral Disease and Orthopaedic Surgeons: COVID-19 PANDEMIC
}

\author{
*Edomwonyi E.O. ${ }^{1}$, Anyaehie, U.E. ${ }^{2}$, Onuminya, J.E. ${ }^{3}$
}

\begin{abstract}
Background: COVID-19 is caused by novel Coronavirus Severe Acute Respiratory Syndrome-Corona Virus (SARS-Cov-2). It is purported to have originated from bat in Wuhan province of China in December, 2019. The epidemic spreads rapidly, reaching a pandemic proportion in January, 2020. The economic implications of the pandemic and burden on health care are enormous. We, therefore, review the impact of this disease to orthopaedic practice.
\end{abstract}

Methods: A comprehensive review of the literature, using suitable keywords, such as COVID -19, viral disease, orthopaedic surgery, on the search engines of PUBMED, Google Scholar and SCOPUS in June 2020.

Results: The current treatment of COVID-19 is largely supportive. Lockdown, social distancing, are among many social preventive measures that had been adopted in an attempt to halt the spread of this disease. These Social adjustments, are achieving remarkable results. Intensive monitoring is key. Profound modifications had been made in all spheres of orthopaedic practice, suspending elective surgical cases and modifying the handling of inpatients and outpatients.

Conclusions: Globally, orthopaedic practice has been altered in elaborate terms, to accommodate peculiarities of this emerging viral disease, COVID-19. Whilst not neglecting the needs of our patients who depend on us for due care, strict precautions have been adopted to protect patients and health care workers or halt the spread of the disease.

Key words: COVID-19, pandemic, orthopaedic surgeon

*Corresponding author

Edomwonyi, E.O.

Email: edomwonyi1971@gmail.com

${ }^{1}$ Department of Orthopaedics and Traumatology, Irrua Specialist Teaching Hospital Irrua, Nigeria ${ }^{2}$ Department of Orthopaedics and Traumatology, National Orthopaedic Hospital, Enugu, Nigeria

${ }^{3}$ Department of Orthopaedics and Traumatology Faculty of Clinical Sciences, College of Medicine, Ambrose Alli University, Ekpoma, Nigeria 


\title{
Maladies virales émergentes et chirurgiennes orthopédiques: Pandémie de COVID-19
}

\author{
*Edomwonyi E.O. ${ }^{1}$, Anyaehie, U.E. ${ }^{2}$, Onuminya, J.E. ${ }^{3}$
}

\begin{abstract}
Résumé
Contexte général de l'étude: Le COVID-19 est causé par le nouveau coronavirus syndrome respiratoire aigu sévère-virus Corona (CSRSVC-Cov-2). Elle est censée provenir de chauve-souris dans la province de Wuhan en Chine en décembre 2019. L'épidémie se propage rapidement, atteignant une proportion pandémique en janvier 2020. Les implications économiques de la pandémie et le fardeau sur les soins de santé sont énormes. Nous examinons donc l'impact de cette maladie sur la pratique orthopédique.
\end{abstract}

Méthode de l'étude : Une revue complète de la littérature, en utilisant des mots clés appropriés, tels que COVID -19, maladie virale, chirurgie orthopédique, sur les moteurs de recherche de PUBMED, Google Scholar et SCOPUS en juin 2020.

Résultat de l'étude : Le traitement actuel du COVID-19 est largement favorable. Le verrouillage et la distanciation sociale font partie des nombreuses mesures de prévention sociale adoptées pour tenter de stopper la propagation de cette maladie. Ces ajustements sociaux donnent des résultats remarquables. Une surveillance intensive est essentielle. De profondes modifications ont été apportées dans tous les domaines de la pratique orthopédique, suspendant les cas chirurgicaux électifs et modifiant la prise en charge des patients hospitalisés et ambulatoires.

Conclusion: À l'échelle mondiale, la pratique orthopédique a été modifiée en termes élaborés, pour tenir compte des particularités de cette maladie virale émergente, le COVID-19. Tout en ne négligeant pas les besoins de nos patients qui dépendent de nous pour les soins appropriés, des précautions strictes ont été adoptées pour protéger les patients et les agents de santé ou enrayer la propagation de la maladie.

Mots-clés: COVID-19, pandémie, chirurgien orthopédique

*Corresponding author

Edomwonyi, E.O.

Email: edomwonyi1971@gmail.com

${ }^{1}$ Department of Orthopaedics and Traumatology, Irrua Specialist Teaching Hospital Irrua, Nigeria ${ }^{2}$ Department of Orthopaedics and Traumatology, National Orthopaedic Hospital, Enugu, Nigeria

${ }^{3}$ Department of Orthopaedics and Traumatology Faculty of Clinical Sciences, College of Medicine, Ambrose Alli University, Ekpoma, Nigeria 


\section{INTRODUCTION}

SARS- COV-2 is the cause of the novel corona virus disease 2019(COVID-19). It is one of seven different strains of corona virus (1). The others are 229E (alpha coronavirus), NL63 (alpha coronavirus), OC43 (beta coronavirus), HKU1(beta coronavirus), MERS-Cov, Sars-Cov are others. They are zoonoses, with Chinese horse shoe bats, (Rhinolophiss sinicus) being the most likely origin $(2,3)$. In Dec 2019, this novel coronavirus was identified as a cause of respiratory tract infection in Wuhan, a city of Hubei province of China. It spread rapidly, reaching a pandemic proportion, and affected people in all continents except Antarctica. In January 30, 2020, World Health Organization (WHO), acknowledged and declared it a public health emergency of international concern (4), and in February 11, 2020, the disease was designated COVID-19 which stands for coronavirus disease 2019 (5).

The emergence of Covid-19 has impacted seriously on orthopedics globally. In the interim, orthopaedic surgeons were advised, by their academic and professional bodies to delay, postpone or cancel elective surgeries, as an attempt to halt the spread of the disease and protect health care workers. As a result, a rise in the number of Orthopaedic patients, delay in treatment, increase morbidity were strongly anticipated. The opportunities and robustness of facilities and manpower in the developing nations are lacking. Hence, those patients having elective surgery delayed or cancelled, in fact, may never get such surgeries done.

The incubation period of COVID-19 is approximately 4-14 days following exposure $(6,7)$. In a report (8) from China center for disease control and prevention with 44,500 confirmed infections, the spectrum of severity was mild (no or mild pneumonia) $81 \%$, severe disease $14 \%$, critical disease 5\%. Another multicenter study (7) of 1099 patients, revealed that $15.7 \%$ met the criteria of severe pneumonia. Overall case fatality rate (CFR) was $2.3 \%$; no death was recorded among non-critical cases. However, this CFR rose to $8 \%$ among those $70-79$ years, $14.8 \%$ in those above 80 years and $49 \%$ in those in intensive care units (ICU) (8). Some co-morbid medical conditions such as diabetes mellitus, malignancies, hypertension, chronic lung disease, cerebrovascular disease are believed to increase the risk of mortality (8). No age group is exempted and asymptomatic cases are well established. In South Korea, $6.3 \%$ of nearly 8000 infections were among patients less than 20 years of age (9) and 2\% was reported in a similar survey in China (8).

Pneumonia is the most frequent serious manifestation of this disease. No specific clinical feature can yet reliably distinguish Covid-19 from other viral infections. The common clinical manifestations at the onset of illness were $(7,10)$, fever $88-99 \%$, dry cough $59-68 \%$, anorexia $40 \%$, fatigue $38-70 \%$, myalgia $15-31 \%$, arthralgia, osteoporosis, osteonecrosis $5-58 \%$ majority involve the femoral head, albeit, knee, humeral head, talus, calcaneus are affected in lesser frequencies, dyspnea $19-31 \%$, productive sputum $27-34 \%$. Other less common symptoms are, headache, sore throat, rhinorrhea, gastrointestinal (nausea and diarrhea) (10), loss of smell and taste. ARDS is a major common complication in patients with severe disease (11).

This article critically examines this emerging viral disease and its impact on orthopaedic surgeons and practice.

\section{Aetiology and Transmission}

COVID-19 is a disease caused by a beta coronavirus that belong to the RNA encapsulated viruses family (12). There was an earlier association with a market in Wuhan, where most patients had worked and visited (5). However, later on, human-human transmission through formites and droplets became established modes of spread. When an infected person coughs, sneezes or talks, the virus is released into respiratory secretions. Expectedly, symptomatic patients are the most contagious. However, asymptomatic carriers (super spreaders) have been demonstrated to spread the covid-19, albeit, it is not thought to be a common occurrence (12, 13, 14).

Among orthopedic patients, some depend on walking aids such as crutches, canes, walkers, wheel chairs and prosthetic devices for ambulation. These items trap droplets and get contaminated. While handling or cleaning these materials, orthopaedic patients sometimes acquire this infection. Health care professionals are not spared. They encounter these virus during clinical examination, transportation of patients, intubation, noninvasive ventilation, bronchoscopy, and during aerosol generating procedures involving powered tools (15).

\section{Epidemiology}

Nations all over the world have reported increasing number of cases. The US, Spain, UK and Italy were the most seriously affected. Following closely were Germany and France. 
West Pacific region (China, Korea, Japan, Malaysia, Australia) Eastern Mediterranean region with Iran were not spared (16). The rapidity of spread of this disease is enormous, as shown on table 1.

Shown in figures 1, 2 and 3 are cases, deaths recorded and geographical distributions worldwide as at May 31, 2020.(17) Ten deaths and 800 cases were reported among passengers travelling in cruise ship (18).

The figures are considered an underestimation as the number of asymptomatic individuals is unknown and testing facilities vary from region to region (19). Among the most susceptible are frontline health care workers $(\mathrm{HCW})$, residents in elderly people's homes, hospices, nursing homes, aged, patients with underlying disease or medical comorbidities (20). Figure 1 showed the cases reported in accordance with the applied case definition and testing strategies in the affected countries while figure 2 showed the distribution of Covid -19 deaths worldwide by continent. Reports claim that $3300 \mathrm{HCW}$ in China and 20\% of HCW in Italy have contracted the infection (21). In Nigeria, the number of $\mathrm{HCW}$ that contracted this infection rose from 40 in April 24, 2020 to 113 in May 1,2020 (22). The risk is expected to rise astronomically, with the shortage of personal protective equipment (PPE) globally and longer hours of work expected from $\mathrm{HCW}$ as they deal with the rising number of cases.

The case fatality rate (CFR) was reported as $2-7 \%$, depending on the patient's age and presence of co-morbidities $(23,24)$. Data from the US revealed that, among 20-44years, $20 \%$ were hospitalized and $12 \%$ admitted into intensive care unit (ICU) (20). Another study In Italy, a nation with a higher CFR, recorded that $60 \%$ of cases and $70 \%$ of deaths were in men. A Similar survey in China reported that 64\% mortality in men (25).

\section{Pathogenesis}

SARS-Cov-2 belong to the betacoronaviruses. It is elliptic, with a diameter of approximately $60-140 \mathrm{~nm}$ as shown in Fig. 4. Identified as functional receptors for SARSCOV-2 are angiotensin converting enzyme2(ACE-2) and transmembrane protease serine 2 (TMPRSS-2). They and other multiple nonneuronal cell receptors are found in the olfactory and respiratory epithelia $(26,27)$. This facilitates SARS-Cov-2 binding, replication and accumulation. Thus explains why clinical samples from these sites are considered appropriate for early detection of the virus and the recently reported cases of smell dysfunction among patients with Covid-19. The lungs, heart, ileum, kidney and bladder are other organs where ACE-2 receptors are elaborately expressed (28). The disease progression is divided into 3 distinct phases

1. Early infection phase

2. Pulmonary infection phase

3. Severe hyperinflammatory phase

Many patients may be asymptomatic, yet are viral shedders and infective.

Early infection phase is marked by local symptoms like sore throat, unproductive cough, headache, and myalgia. Large numbers may not progress beyond this phase.

In the Pulmonary phase, dominant site is the lung. This virus invades the apical part of the lung epithelial cells in the alveolar space, $(29,30)$ where ACE-2 receptors are copiously expressed, causing vasodilatation, endothelial permeability, leucocyte recruitment, leading to pulmonary damage, hypoxemia, and cardiovascular stress. This also explains the early lung injury often seen in the distal airway. In critical cases, respiratory failure occur. Two varieties have been demonstrated, the adult respiratory distress syndrome (ARDS) or type $\mathrm{H}$ patient and the type L phenotype.

Report has earlier reviewed $\mathrm{T}$ cell mediated responses against this virus (31). Some patients with severe disease, develop lymphopenia involving particularly, the peripheral blood $\mathrm{T}$ cells $(32,33)$. $\mathrm{T}$ cell responses are triggered by antigen presentation via dendritic cells (DC) and macrophages. How does SARS-CoV-2 enter antigen presenting cells (APC)? DCs and macrophages may phagocytize apoptotic cells infected by virus (34) which leads to antigen presentation to T cells. Or DCs and macrophages may be infected with virus primarily? Future research would determine this.

In a group of patients, host inflammatory response get exaggerated, results in systemic inflammation, also known as "cytokine storm" with potential to damage distant organs. These patients have been reported to have increased plasma concentrations of pro-inflammatory cytokines, such as interleukin (IL)-6, IL8,IL-10, tumor necrosis factor (TNF)- $\alpha$, granulocytecolony stimulating factor (G-CSF), macrophage inflammatory protein (MIP) $1 \alpha$ and monocyte chemo attractant protein 1 (MCP1) (32,33). IL-8 is a well-known chemoattractant for neutrophils and $\mathrm{T}$ cells. Observed among patients that suffered severe COVID-19, is the Infiltration of the lungs by large number of inflammatory cells 
$(35,36)$. Neutrophils, act as double-edged sword as they too, also induce lung injury $(37,38)$. Severely ill patients also elaborate pathological cytotoxic $\mathrm{T}$ cells derived from $\mathrm{CD}^{+} \mathrm{T}$ cells (39). $\mathrm{CD} 8^{+} \mathrm{T}$ cells are also sensitized, beyond killing the viruses and virus infected cells, they also contribute significantly to lung injury (40). The hyperinflammatory phase has serious effects on many organs, amongst them are the heart, blood vessels, lungs and kidneys. The ensuing respiratory failure also secondarily stress the heart, especially in those with pre-existing heart disease. Cytokine storm, fluid deregulation, cardiac failure, sepsis and rhabdomylysis are other factors that contribute to acute kidney injury.

Thrombosis and pulmonary embolism have been seen in severe cases. Endothelial cells also express $\operatorname{ACE}-2(41,42)$, as a result viral attachment produces endothelial injury and increased coagulability of blood. Of note, the endothelial cells represent the one third of lung cells, (43) they play a significant role in thrombotic regulation (44). The combination of hypercoagulability, vessel inflammation and leucocyte aggregation may adversely affect micro vascular blood flow and contribute to the development of osteonecrosis, seen in some patients with severe disease.

\section{Diagnosis}

The diagnosis is based epidemiological history, clinical features and relevant investigations.

It is noteworthy to say that clinical features of SARS-Cov-2 are highly atypical and epidemiological history. Relevant Investigations include, nucleic acid detection, computerized tomography (CT) scan, point of care testing of immunoglobulin $\mathrm{G}$ ( $\mathrm{IgG}$ ), immunoglobulin M(Ig,M), Enzyme linked immusorbent assays (ELISA), and blood culture.Current diagnostic tests are reverse - transcription polymerase chain reaction (RT-PCR) real time RT-PCR and reverse transcription loop-mediated isothermal amplification (RT-LAMP) $(45,46)$. RT-LAMP has similar sensitivity as rRT-PCR, but it is more specific $(47,48)$. RT-PCR is the most common, efficient, straight forward method for detecting these viruses in secretions (44). Nasopharyngeal and oropharyngeal swabs are the standard assessment for the diagnosis of Covid-19 infection. For early identification, 2 single step quantitative (RT-PCR) were developed to detect 2 different regions (ORFIb and N) of the SARSCov-2 genome(49). The SARS-Cov E gene assay was more sensitive than the RdRp gene assay combine with the one-step RT-PCR system (49) Whilst the E-gene PCR has been adjudged, to be sufficient for diagnosis, the RdRp protocol is recommended for confirmation $(50,51)$.

False negatives results may occur, particularly when the test is done in the early stages. This could be due to any of the following; Less shedding of the virus, improper swab technique, poor swab preservation and transportation and technical limitation inherent to test. Diagnosis, quite often is delayed, because of shortage of commercial testing kits and current lab tests are time consuming. Clinically symptomatic patients, with recent exposure, Covid-19 should be diagnosed with typical chest CT characteristics despite negative RT-PCR results (52). A recent study of 1014 patients revealed that $59 \%$ had positive RT-PCR results and $88 \%$ had a positive chest CT findings (53). Bilateral parenchyma ground glass and consolidative pulmonary opacities, are the typical CT findings (52). Notably, Lung cavitation, discrete pulmonary nodules, pleural effusion and lymphadenopathy were absent (54). Combining clinical, laboratory findings with imaging features could facilitate early diagnosis of Covid-19 pneumonia $(55,56,57)$.

\section{HEALTH CARE BURDEN OF COVID-19}

In most countries, orthopaedic patients in outpatients and emergency departments in public and private hospitals are many. This situation, is expected to become more challenging for health care professionals, since Covid -19 outbreak. Health care professionals are at risk, particularly anesthetists, during the process of intubation of patients during general anaesthesia (58). In most developing countries, the number of intensive care units (ICU) beds are limited. A significant number of patients requiring surgery are the elderly and may require ICU back up. PPEs are inadequate and surgeons are relatively few in these countries. Covid-19 work up is advised for every patient requiring surgery. The 'HIV model' should be adopted for every emergency case during the Covid-19 pandemic. All patients, unless proven otherwise, should be assumed to be positive and orthopedic surgeons must take appropriate precautions. Contact of the theatre team with known Covid-19 cases should be compelled to observe self-quarantine for 14 days, which will ultimately result in further shortage in the workforce. 
Management tips as it applies to the orthopedic surgeon

Outpatients department (OPD)

Appointments are scheduled in such a way that unnecessary physical consultations are avoided while encouraging phone call consultation and telemedicine practice. Waiting area should be kept vacant and social distance observed by all. Strict hand hygiene is strongly advised. Maintain social distance.

One attendant to a patient, all including staff must wear face mask. Health care professionals should wear scrubs, masks, gloves, and hospital shoes. Assessment room should be separate from procedure room. One stop treatment, minimal follow visits, minimal X-rays and investigations, C-arm shifted to OPD, to avoid visit to radiology, triaging for surgery, important to avoid unnecessary admissions. Avoid routine operations, particularly in the geriatric patients. Use health care resources wisely. Preoperative workup. History of symptom/travel history to hotspots/contact. Routine pre-operative work up. Test for Covid-19 because of asymptomatic shedders and potential risk of exposing health workers to the virus

If regional /institutional guidelines does not allow, do chest CT scan. Advantages include sensitivity, ease and pace of reporting. Disadvantages, particularly in resource challenged are inaccessibility and cost. CT Chest can be used as a screening tool for patients being planned for surgery for possibility of incipient pneumonitis. If CT findings are positive, do RTPCR even if asymptomatic; if CT/PCR findings are negative with negative history, one can proceed as with normal operating theatre precautions BUT N95 MASK /TAPE SEALED SURGICAL MASK WITH FACE SHIELD \& WATERPROOF GOWNS/WATERPROOF APRONS MUST BE USED IN ALLAEROSOL G E N E R A T I N G P R O C E D U R E S, IRRESPECTIVE OF COVID STATUS DURING PANDEMIC

\section{Planning Surgery list}

Avoid blood transfusions as blood safety is questionable.

Screen and clinically evaluate blood donors

No surgery at nights where possible

Review resources, staff and ventilator availability, PPE kits

Where possible, manage conservatively, except where surgical intervention is absolutely necessary.

Discuss with all relevant stakeholders, anesthetists, paramedics, nurses and staff of other surgical departments etc

Be wary of the risk of COVID-19 nosocomial infection and prepare ahead

\section{Consent}

Counselling should be done using advanced techniques like e-mail, whatsapp, telemedicine, virtual reality, or holography

Explain to the patient about extra cost due to PPE, extra precautions

Risk of exposure if patient is negative

High risk of morbidity and mortality (mortality $20.5 \%$ ) if found to be Covid-19 positive later. [59]

PPE donning area should be separate from the main suite.

Patient movement

Smooth unrestricted passage to the OT, using dedicated trolleys

A separate if possible standalone theatre suite should be prepared and reserved for COVID-19 patients when they require surgery

Use PPE

Patient to wear mask all the time

Anaesthesia Considerations

Avoid general anaesthesia (GA). Regional anaesthesia is preferred. If GA is inevitable, separate intubation and extubation rooms is advised.

All anesthetists and assistants fully kitted with PPE

Operating theatre (OT) Considerations

Dedicated OT for Covid-19 cases/ suspected patients

Negative pressure OT

No laminar flow

Minimal essential OT personnel

Minimal equipment inside the theatre with removal of all not needed for the case, cover shelves and difficult to remove machines with drapes prior to surgery

\section{Intraoperative Considerations}

Avoid cautery, if must, it should be used minimally with low settings and using smoke evacuator

Minimize bleeding: use tourniquet/tranexamic acid/good hemostasis

No pulse lavage/high pressure lavage, do gentle lavages

No power tools. Osteotome, manual reamers, nibblers etc are preferred

Avoid staged surgeries

Use absorbable sutures

Avoid large wound dressing where possible, 
visible dressings like opsite, tegaderm preferred. This allows wound inspection from a safe distance.

Removable splints/slabs is advised instead of casts. Risk of contact with patient is higher while removing a cast. It is also easier to remove the splints at home.

Post-operative Considerations

PPE should be removed outside OT, following the appropriate sequence eye wear, face shield/gown, and then wash/hand rub

Remove mask outside the theatre and discard properly

Shift patient to the recovery room

Minimize postoperative stay

Rehabilitation program using videos and telemedicine, encourage family members to assist

Minimal follow up visit, give SOS numbers. Allay issues over phone

\section{OT Cleaning}

Clean instrument used separate

All non-dedicated/non disposable equipment should be cleaned including $\mathrm{C}$-arm using institutional/manufacturer's guidelines. $70 \%$ ethyl alcohol to disinfect re-usable dedicated equipment between uses.

Sodium hypochlorite $1 \%$ for disinfection of frequently touched surfaces.

Linen Clearing

Soiled linen should be segregated in labelled containers

Wash and disinfect in warm water 60-90 degrees and detergent. If hot water is not available, soak linen in $0.05 \%$ chlorine solution for $30 \mathrm{~min}$

Rinse with clean water and dry in sunlight.

Expectations post Covid-19

High index of suspicion, keeping to precautionary measures when operating on suspects

Handling the sudden rush and rescheduling of patients for elective surgeries

Nationwide industry supports for production of PPEs and other resources

Gradual easing of lockdown to allow for herd immunity and economy picks up while still encouraging mass masking and social distancing.

Psychological Support

Stress, fear and anxiety

Suicide, hysteria, emotional instability are consequences

Family members, HCP are advised to provide social support.

Adequate pretest counselling

\section{Preventive measures in Covid-19}

Strategies for prevention of transmission and infection are

1. Non pharmacologic-voluntary quarantine at home, social distancing $(2 \mathrm{~m})$ of population at risk like closure of schools, ban on social gathering eg religious, burial, weddings etc. This helps to break the chain of transmission (44). Hand washing, compulsory use of face masks when out of homes, healthy diets exercises, good dose of early morning sunshine and daily public sensitization on keeping safe.

2. Pharmacologic intervention include

a.Antiviral agents

b.Chloroquine, hydroxychloroquine, Azithromycin,

c. Vit C, Vit D, zinc

Those on the above medications should be monitored regularly for hematological parameters like serum electrolyte and urea, blood sugar, liver function test. Routine electrocardiogram (ECG) is essential before commencement.

\section{CONCLUSION}

Covid-19 pandemic is a public health emergency of international concern, nations need coordinated international drive to fight it. Recently, the Surgical Royal Colleges of the UK and Ireland have issued guidance for the surgeons working during the Covid-19 pandemic.

Covid-19 pandemic has thrown up a major challenge, creating large number of patients rapidly, whose elective cases were deferred while profound adjustments are being made in handling both inpatients and outpatients in the orthopaedic departments, leading to further strain on the scarce human and material resources of many nations particularly the developing countries. Health care professionals must brace up to handle this, to save humanity at risk of acquiring this infection.

Isolation and quarantine, social adjustments are achieving remarkable results. Intensive monitoring is key. As a sense of duty, we must keep abreast of developments, review and adjust our orthopaedic practice appropriately, strengthen, sharpen our skills and resilience in handling this infectious disease outbreak, without neglecting the needs of our patients who depend on us for due care.

On the positive end, advantages derived from this pandemic, are opportunities for orthopaedic surgeons to finish pending jobs like research, 
publications, spared radiological exposure, less work, stress and spending quality time with their families.

\section{Conflict of Interest: None declared}

Funding: None was received from any organization or corporate body

\section{REFERENCES}

1. National Center for Immunization and Respiratory Diseases( NCIRD), Division of viral diseases.

2. Chan JF, Yuan S, Kok KH, Chu H, Yang J, Xing F, Liu J, Yip CC, Poon RW, et al. (2020). A familiar cluster of pneumonia associated with 2019 novel coronavirus indicating person-person transmission: a study of a family cluster. Lancet. 395(10223):514-523

3. Lu R, Zhao X, Li J, Niu P, Yang B, Wu H, Wang W, Song H, Huang B, ZhuN, et al( 2020). Genomic Characterization and epidemiology of 2019 novel coronavirus: implications of virus origins and receptor binding. Lancet 395(10224):565-574.

4. Mahase E. (2020). China coronavirus: WHO declare Int. emergency as death toll exceeds 200. BMJ. 2020 Jan 31;368:m408. doi: 10.1136/bmj.m408.

5. WHO. DG's remarks@the media briefing on 2019-Cov on 11 feb (2020). Retrieved from: https://www.who.int/dg/speeches/detail/whodirector-general (Accessed on feb12, 2020).

6. Li Q, Guan X, Wu P, Wang X, Zhou L, Tong, et al Jan (2020). Early transmission dynamics in Wuhan, China of novel coronavirus-infected pneumonia. N. Engl. J. Med. 382:1199-1207. DOI:10.1056/NEJMoa2001316.

7. Guan W-j, Ni Z-Y, Hu Y, Liang W-h, Ou c-q, He J, et al. Apr(2020) Clinical characteristics of 2019 novel coronavirus infection in China. N. Eng J. $\mathrm{M}$ e d $\quad 382: 1708-1720$. DOI:10.1056/NEJMoa2002032.

8. Wu Z, Mc Coogan JM. Feb(2020) Characteristics of and importance lessons from the corona virus disease 2019(Covid 19) outbreak in China: Summary of report of 72,314 cases from the Chinese center of disease control and prevention. JAMA. Doi:10.1001/jama.2020.2648. Online ahead of print

9. Park JY, Han MS, Park Ku, Kim JY, Choi EH. Mar (2020) First paediatric case of coronavirus disease in 2019 in Korea. J. Korean. Med. Sci.35(11):e124.doi10.3346/jkms.2020.35.e124

10. Wang D, Hu B, Hu C, Zhu F, Liu X, Zhang J, et al.Feb(2020) Clinical characteristics of 138 hospitalized patients with 2019 novel coronavirus-infected pneumonia in Wuhan, C h i na. J A M A.323(11): 1061 1069.doi:10.1001/jama.2020.1585.

11. Huang C, Wang Y, Li X, Ren L, Zhao J, Hu Y, et al. $\mathrm{Feb}(2020)$ Clinical features of patients infected with 2019 novel coronavirus in Wuhan, China. The Lancet, 395(10223):497-506

12. Neeltje van Doremalen, phD.; Trenton Bushmaker, BSc;et al;NEJM. Mar (2020) Aerosol and Surface stability of SARS-Cov-2 as compared with SARS-Cov-1;Doi10.1056/NEJMc2004973.

13. Van Doremalen N, Bushmaket T, Morris D. Aerosol and surface stability of Covid -19(SARSCov-2) c o m p a r e d to S A R S Cov)medRxiv(2020);http//doi.org/10.1101/2020. 03.09.20033217

14. WHO. Advice on the use of masks in the Community, during home care and in healthcare settings in the context of the novel coronavirus (2019nCov) outbreak. Jan 29,(2020). https;//www.who.int./publications-detail/adviceon-the -use-of-mask-in-the-community-duringhome-care-and-in-the-healthcare-settings-in-thecontext-of-the-novel-coronavirus-(2019-nCov)outbreak.

15. Expert consensus on preventing nosocomial transmission during respiratory care for critically ill patients infected by 2019 novel coronavirus pneumonia. Zhonghua jie he he hu,xi, za zi $=$ Zhonghua jiehe he huxi za $\mathrm{zhi}=$ Chinese journal of T.B and respiratory diseases. (2020);17(0);E020.

16. WHO. Coronavirus disease (Covid-2019) situation reports. March 27,(2020). https://www.who.int/docs/default source/coronavirus/situation-reports/20200327sitrep-67-covid-19.pdf?sfvrsn=b65f68eb_4

17. https://www.ecdc.europa.eu/sites/default/files/ styles/is_full/public/images/COVID-19geographical-distribution-world-cumulative$\mathrm{n} \mathrm{u} \mathrm{m} \mathrm{b} \mathrm{e} \mathrm{r}-14-\mathrm{d}$ a y $-2020-05-$ 31.jpg? itok=qgTK_JLX(Accessed May $31,(2020)$

18. Moriarty LF, Plucinski MM, Marston BJ. Public Health Responses to Covid-19 outbreaks on Cruise ships-Worldwide, Feb-Mar (2020) MMWR Morb. Mortal. Wkly Report.ePub;23 MR (2020).DOI:http://dx.doi.org/10.155/mmwr.mar6 912e3external icon.

19. Baud D, Qi X, Nielsen-Saines K, Musso D. Pomar L, Favre G. Mar 12,(2020) Real estimates of mortality following Covid -19 infection, The Lancet infectious diseases. Online agead of print. https://doi.org/10.1016/S1473-3099(20)30195-X

20. Mc Micheal TM, Currie DW, Clerk S, Pogosjans S, Kay M, Schwartz NG, et al.(2020) Epid. Of Covid-19 in a long-term care Facility in king County, Washington. New Eng J. of Med. (2020)

21. The L. Covid-19: (2020) Protecting health-care workers. The Lancet.;395(10228):922

22. Punch Nigerian newspapers $1 \mathrm{mar}, 2020$

23. Siverdlow DL, Finelli . (2020), Preparation for possible sustained transmission of 2019 Novel coronavirus: Lessons from previous epidemics. Jama.323(12)1129-30

24. Livingstone E. Bucher K. (2020)Coronavirus Disease 2019(Covid-19) in Italy.Jama.2020 
25. Anwaerter PG. Coronavirus Covid-19(SARSCov-2). John Hopkins ABX Gude. http://www.hopkinsguides.com/hopkins/view/jo

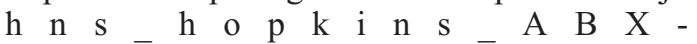
Guide/540747/all/coronavirus_covid_19_SAR S- Cov 2

26. Oū X, Liu Y, Lei X, Li P, Mi D, Ren L, et alMar(2020). Characterization of Spike glycoprotein of SARS-Cov-2 on virus entry and its immune cross-reactivity with SARS-Cov. Nat. Commun.11,1620(2020).10.1038/s41467-02015562-9.

27. Hoffman M; Kleine-Weber H; Schroeder S; Kruger N; Herrler T; Erichsen S; Schiergens ES; Herrler G; Wu N-H; Nitsche A; Muller MA; Drosten C; Pohlman S. Apr(2020) SARS-Cov-2 cell entry depends on ACE2 and TRMPSS2 and is blocked by a clinically proven protease inhibitor. $\mathrm{C}$ e 11181 ( 2 ) : $271-280$. e 8 . doi:10.1016/j.cell.2020.02.052.

28. Zou X., Chen K., Zou J., Han P., Hao J., Han Z. Mar(2020) Single-cell RNA-seq data analysis on the receptor ACE2 expression reveals the potential risk of different human organs vulnerable to 2019$\mathrm{nCoV}$ infection. Frontiers of Medicine 14,185192(2020)

29. Hamming I., Timens W., Bulthuis M.L., Lely A.T., Navis G., van Goor H.June (2004) Tissue distribution of ACE2 protein, the functional receptor for SARS coronavirus. A first step in understanding SARS pathogenesis. Journal of Pathol. 203(2):631-637.

30. Jia H.P, Look D.C., Shi L., Hickey M., Pewe L., Netland J., Farzan M., Wohlford-Lenane C., Perlman S., McCray P.B Jr. (2005)ACE2 receptor expression and severe acute respiratory syndrome coronavirus infection depend on differentiation of human airway epithelia. Journal of Virology. Dec 79(23):14614-14621.doi:10.1128/JVI.79.23.146 14-14621.2005.

31. Channappanavar R., Zhao J., Perlman S.(2014) T cell-mediated immune response to respiratory c o r o n a vi r u s e s. J o u r n a 1 . 59(1):118-128.doi:10.1007/s12026-014-8534-Z

32. Zhou Y., Fu B., Zheng X., Wnag D., Zhao C., Qi Y., Sun R., Tian Z., Xu X., Wei H. Mar (2020) Pathogenic $\mathrm{T}$ cells and inflammatory monocytes incite inflammatory storm in severe COVID-19 patients. National Science Review, nwaa041, https://.org/10.1093/nsr/nwaa041

33. Qin C., Zhou L., Hu Z., Zhang S., Yang S., Tao Y., Xie C., Ma K., Shang K., Wang W., Tian D.S.(2020) Dysregulation of immune response in patients with COVID-19 in Wuhan, China. Clinical Infectious diseasesl. ; ciaa248. doi: $10.1093 / \mathrm{cid} / \mathrm{ciaa} 248$. Online ahead of print.

34. Fujimoto I., Pan J., Takizawa T., Nakanishi Y. Apr(2000) Virus clearance through apoptosisdependent phagocytosis of influenza A virus- infected cells by macrophages. Journal of Vir o log y. 74 ( 7 ): $3399-403$. Doi:10.1128/jvi.74.7.3399-3403

35. Xu Z., Shi L., Wang Y., Zhang J., Huang L., Zhang C., Liu S., Zhao P., Liu H., Zhu L., Tai Y., Bai C., Gao T., Song J., Xia P., Dong J., Zhao J. Apr (2020) Wang F.S. Pathological findings of COVID-19 associated with acute respiratory distress syndrome. The Lancet Journal. 8(4):420-422.

36. Tian S., Hu W., Niu L., Liu H., Xu H., Xiao S.Y.May (2020) Pulmonary pathology of Earlyphase 2019 Novel Coronavirus (COVID-19) pneumonia in two patients with lung cancer. Journal of Thoracic oncology. 15(5):700-704doi: 10.1016/j.jtho.2020.02.010.

37. Liu S., Su X., Pan P., Zhang L., Hu Y., Tan H., Wu D., Liu B., Li H., Li H., Li Y., Dai M., Li Y., Hu C., Tsung A. Nov(2016) Neutrophil extracellular traps are indirectly triggered by lipopolysaccharide and contribute to acute lung injury. 6:37252.doi:10.10.38/srep37252

38. Koutsogiannaki S., Shimaoka M., Yuki K. (2019) The use of volatile anesthetics as sedatives for acute respiratory distress syndrome. Tranl Perioper Pain Med 6(2):27-38. Doi: 10.31480/2330-4871/084. Epub 2019 Feb 21

39. Fang M., Siciliano N.A., Hersperger A.R., Roscoe F., Hu A., Ma X., Shamsedeen A.R., Eisenlohr L.C., Sigal L.J.(2012) Perforin-dependent CD4+ T-cell cytotoxicity contributes to control a murine poxvirus infection. Proc Natl Acad Sci USA. 1099(25):9983-8.doi:10.1073/pnas.1202143190 9.

40. Small B.A., Dressel S.A., Lawrence C.W., Drake D.R., 3rd, Stoler M.H., Enelow R.I., Braciale T.J. (2001) CD8(+) T cell-mediated injury in vivo progresses in the absence of effector $\mathrm{T}$ cells. Journal.194(12):1835-1846.doi:10.1084/jem.19 4.12.1835

41. Lovren F., Pan Y., Quan A., Teoh H., Wang G., Shukla P.C., Levitt K.S., Oudit G.Y., Al-Omran M., Stewart D.J., Slutsky A.S., Oct(2008) Peterson M.D., Backx P.H., Penninger J.M., Verma S. Angiotensin converting enzyme-2 confers endothelial protection and attenuates atherosclerosis. Am J. Physiol Heart Circ Physiol.295 ( 4 ) : H 1377 - H 1384 . Doi10.1152/ajpheart.00331.2008

42. Sluimer J.C., Gasc J.M., Hamming I., van Goor H., Michaud A., van den Akker L.H., Jutten B., Cleutjens J., Bijnens A.P., Corvol P., Daemen M.J., Heeneman S.(2008) Angiotensin-converting enzyme 2 (ACE2) expression and activity in human carotid atherosclerotic lesions. J. Pathol.;215(3):273-279.doi:10.1002/path.2357.

43. Zeng H., Pappas C., Belser J.A., Houser K.V., Zhong W., Wadford D.A., Stevens T., Balczon R., Katz J.M., Tumpey T.M.(2012) Human pulmonary microvascular endothelial cells support productive replication of highly pathogenic avian influenza viruses: possible involvement in the pathogenesis of human H5N1 
virus infection. J. Virol. 86(2):667-678.doi:10.1128/JVI.06348-11.

44. Wang M., Hao H., Leeper N.J., Zhu L., Early Career C. June(2018). Thrombotic regulation from the endothelial cell perspectives. Arterioscler Thromb Vasc Biol. 38(6):e90-e95.doi:10.1161/ATVBAHA.118.310 367.

45. Bhadra S, Jiang YS, Kumar MR, Johnson RF, Hensley LE, Ellington AD. Apr(2015) Real time sequence-validated loop-mediated isothermal amplification assays for detection of middle East respiratory syndrome coronavirus(MERS-Cov) 10(4):e0123126.doi:10:1371/journal.pone.01231 26.eCollection 2015 .

46. Chan JF, Choi GK, Tsang AK, Tee KM, Lam HY, Yip CC.(2015) Development and evaluation of novel coronavirus real time reverse transcriptionPCR Assays with locked nucleic acid probes targeting leader sequences of human pathogenic coronaviruses. J. Clin. Microbiol. 53:27222726.doi10.1128/JCM.01224-15

47. Huang $\mathrm{P}$, Wang $\mathrm{H}$, Cao Z, Jin H, Chi H, Zhao J.(2018) A rapid and specific Assay for the detection of MERS-Cov. Front Microbiol. 9:1101.doi.10.3389/fmicb.2018.01101

48. Lee SH, Baek Y.H, Kim YH, Choi YK, Song MS, Ahn JY. Jan(2017) One pot reverse transcriptional loop-mediated isothermal amplification (RTLAMP) for detecting MERS-Cov. Front $\begin{array}{lllllllllll} & \text { i } & c & r & o & b & i & 0 & 1\end{array}$. 7:2166.doi:10.3389/fmicb.2016.02166.eCollecti on 2016

49. Chu DKW, Pan Y, Cheng SMS, Hiu KPY, Krishnan P, Liu Y. Apr (2020) Molecular diagnosis of a novel coronavirus(2019-nCov) causing an outbreak of pneumonia. Clin.Chem 66(4:)549555.doi:10.1093/clinchem/hvaa029

50. VM Corman, O.Landt, M. Kaiser et al. Detection of 2019 novel coronavirus(2019-nCov) by real time RT-PCR Euro Surveill. 25(3):2000045. h t t p s://doi.org/10.2807/1560 7971.ES.2020.25.3.2000045.

51. Cordes AK, Heim A. Feb (2020) Rapid random access detection of the novel SARS coronavirus2(SARS-Cov-2, previously 2019-nCov) using an open access protocol for the Panther fusion. J Clin V i r o 1. $125: 104305$. Doi.10.1016/j.jcv.2020.104305.
52. Xie X, Zhong Z, Zhao W, Zheng C, Wang F, Liu J. Feb (2020) Chest CT for typical 2019-nCov pneumonia: relationship to negative RT-PCR $\mathrm{t}$ e $\mathrm{s} \mathrm{t}$ i n $\mathrm{g}$. $\mathrm{R}$ a d i o 1 . https://doi.org/10.1148/radiol.2020200343.

53. Ai T, Yang Z, Hon H, Zhan C, Chen C, Lv W. Feb(2020) Correlation of chest CT and RT-PCR testing in coronavirus disease2019(Covid-19) CT and RT-PCR testing in coronavirus disease(Covid-19) in China: A report of 1014 c a s e s . R a d i o 1 . https://doi.org/10.1148/radiol.2020200642.

54. Chung M, Bernheim A, Mei X, Zhang, Huang M, Zeng X. Feb (2020) Ct Imaging features of 2019 novel coronavirus (2019) Radiol.295, No 1 https://doi.org/10.1148/radiol.202020030.

55. Shi H, Han X, Jiang N, Cao Y, Alwulid O, Gu J.Feb (2020) Radiological findings from 81 patients with Covid-19 pneumonia in Wuhan, China: a descriptive study. Lancet infect Dis.20(4):425434. DOI:https://doi.org/10.1016/S1473-33099 (20)30086-4.

56. Xu X, Yu C, Ou J, Zhang L, Jiang S, Huang D. Imaging and clinical features of patients with 2019 novel coronavirus SARS-Cov-2. Feb (2020) Eur J. Nucl Med Mol Imaging 47(5):1275-1280. Doi: 10.1007/s00259-020-04735-9.

57. Wang Y, Kang H, Liu X, Tong Z. (2020) . Combination of RT-PCR testing and clinical features for diagnosis of Covid-19 facilitates management of SARS-Cov-2 outbreak. J.Med. virol.2020 https://dpi.org/10.1002/jmv.25721

58. Centre for disease control and prevention. Infection control in health care facilities. Supplemenal: infection control in health care, home and community settings. Public health guidance for community level preparedness and response to severe respiratory syndrome (SARS). Version 2/3. Atlanta GA: CDC,2004. Available at. http//www.cdc.gov/sars/guidance/iinfection/health care.pdf.

59. S Lei et al (2020). Clinical characteristics and outcomes of patient undergoing surgeries during the incubation period of Covid-19 infection. E Clinical med. https://doi.org/10.1016/j.eclinm. Apr 4,2020.100331

How to cite this article:

Edomwonyi E.O., Anyaehie, U.E., Onuminya, J.E. Emerging Viral Disease and Orthopaedic Surgeons: COVID-19 PANDEMIC. Research Journal of Health Sciences, 2021, 9(2): 121-132 
Table 1: Confirmed cases and mortalities

\begin{tabular}{lll}
\hline Date & Covid -19 cases & Deaths \\
\hline Mar 14,2020 & 142,543 & 5,392 \\
Mar 19,2020 & $2,373,850$ & 152,551 \\
May 31,2020 & $6,028,135$ & 368,944 \\
\hline
\end{tabular}

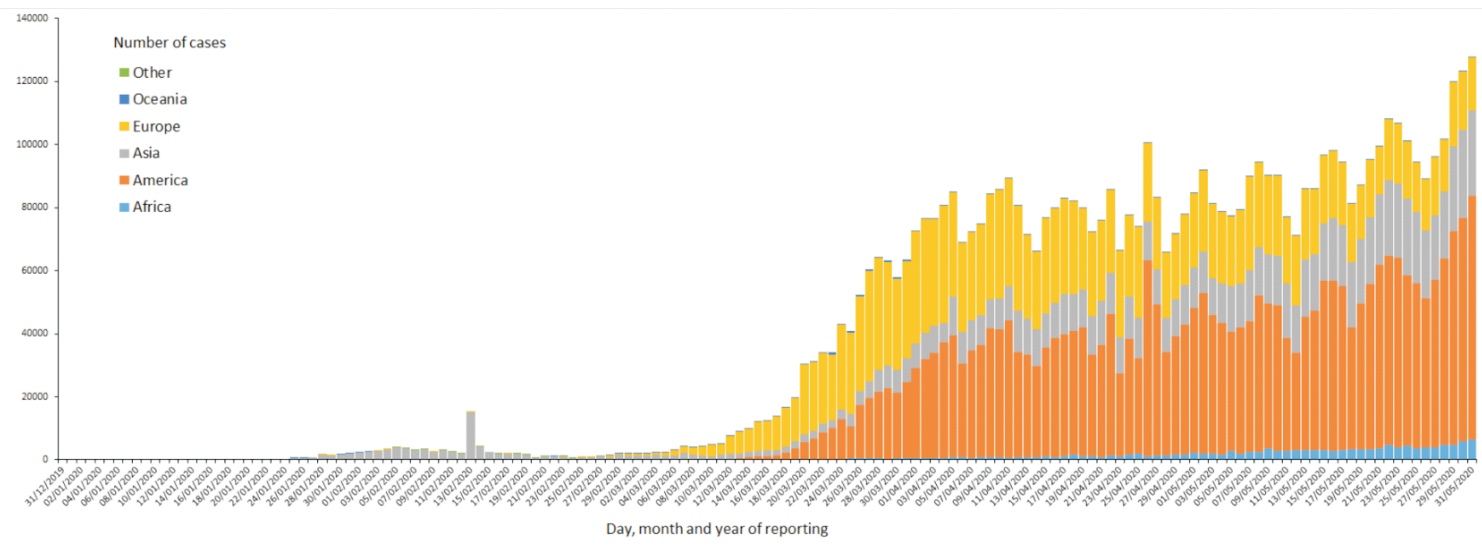

Figure 1. Distribution of COVID-19 cases worldwide, as of 31 May 2020

Cases reported in accordance with the applied case definition and testing strategies in the affected countries.

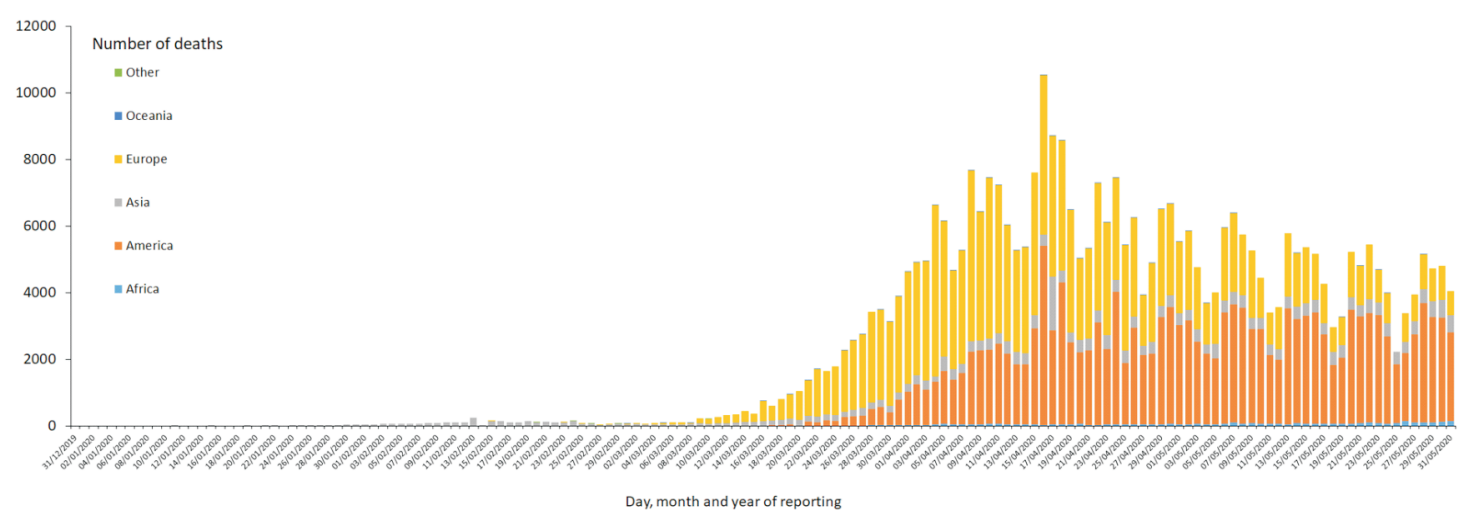

Figure 2. Distribution of COVID-19 deaths, worldwide, as of 31 May 2020 Distribution of Covid -19 deaths worldwide by continent 

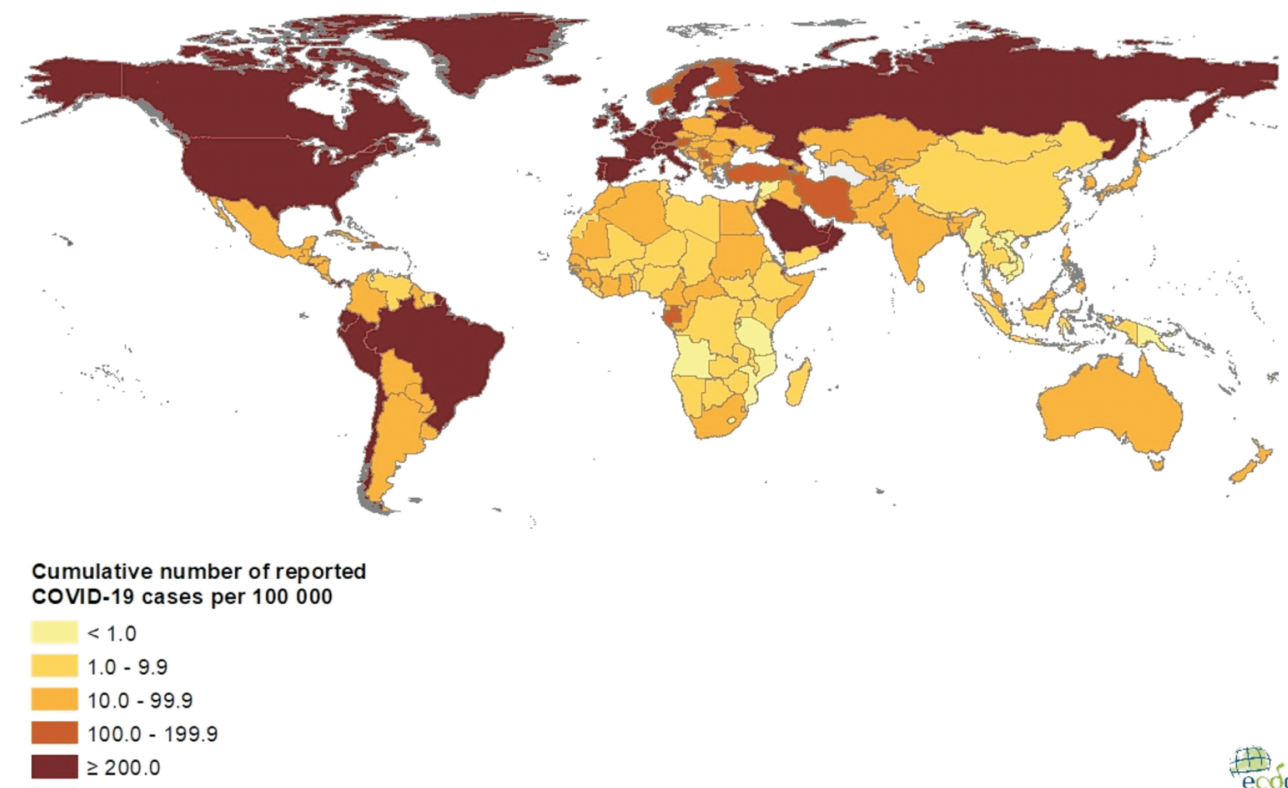

Figure 3. Geographic distribution of cumulative number of reported COVID-19 cases per 100000 population, worldwide, as of 31 May 2020

\section{COVID-19}

Medscape

The virus associated with the outbreak originating in Wuhan, China, has been designated severe acute respiratory syndrome coronavirus 2 (SARS-CoV2). The disease caused by that virus is now officially called COVID-19.

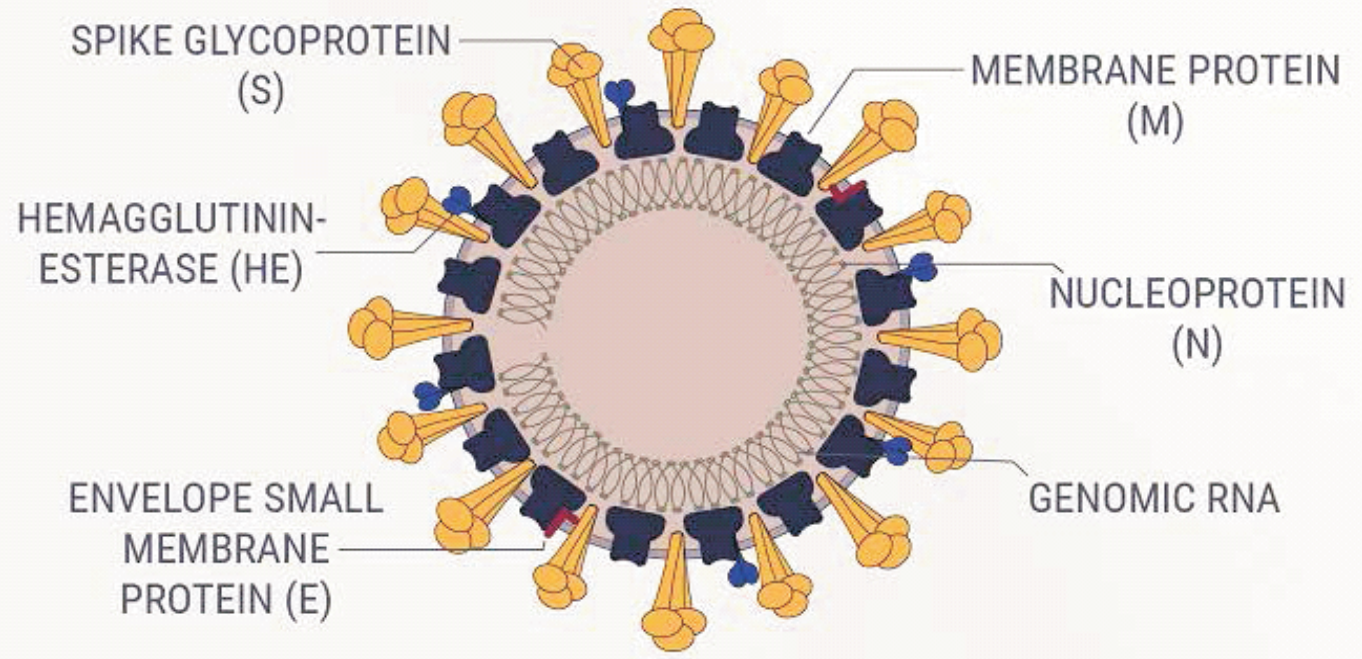

Figure 4. Features of SARS-COV-2 coronavirus. 